\title{
JAPOŃSKA POEACZZONA FLOTA W II BITWIE POD GUADALCANAL, 14-15 LISTOPADA 1942 R.
}

Prowadzona od sierpnia 1942 r. kampania morska na Wyspach Salomona koncentrowała się głównie na akwenach okalających Guadalcanal. Doszło tam do wielu starć, w których Połączona Flota odnosiła spektakularne zwycięstwa, tak jak w bitwie pod Savo (8-9 sierpnia 1942 r.) lub ponosiła klęski, czego przykładem była bitwa koło przylądka Ésperance (11-12 października 1942 r.). Po październiku 1942 r. wyczuwalne było przesilenie w kampanii. Obie strony chciały jak najszybciej zakończyć bitwę, która kosztowała tak wiele sił i środków. Jednym z elementów były wydarzenia mające miejsce w listopadzie 1942 r. Uzupełnienia dostarczane na Guadalcanal przez japońskie niszczyciele działające w ramach „Tokyo Express”1 okazały się niewystarczające. Innym problemem strategicznym było znajdujące się w rękach Amerykanów lotnisko Henderson Field. Obiekt zapewniał panowanie w powietrzu i ograniczał swobodę działania Japończyków. Ten niefortunny splot okoliczności wymógł na sztabie Połączonej Floty obowiązek zmiany sytuacji strategicznej. Zdecydowano o przeprowadzeniu dwóch ważnych akcji, polegających na dostarczeniu znacznej ilości posiłków oraz eliminacji lotniska Henderson Field. Ich efektem były duże, klasyczne starcia artyleryjskie ${ }^{2}$. Drugie ze zdarzeń, do dziś nazywane II bitwa morska pod Guadalcanal, jest przedmiotem niniejszego tekstu.

Po zakończeniu I bitwy pod Guadalcanal siły Połączonej Floty i US Navy przegrupowały się. Spośród tych drugich w rejonie pozostały okręty tworzące Task Force 16 pod dowództwem wiceadmirała Williama Halseya ${ }^{3}$. Amerykanie posiadający dobrze rozbudowaną sieć zwiadu lotniczego zdawali sobie sprawę z przebywania w okolicy wyspy Guadalcanal dwóch formacji okrętowych. Pierwszą z nich był Zespół Zewnętrznych Mórz Południowych, zwany też 8. Flotą, składający się

1 „Tokyo Express” - określenie to zostało stworzone przez Aliantów i opisywało okręty Połączonej Floty, które pod osłoną nocy dostarczały na Guadalcanal żołnierzy, zaopatrzenie i uzbrojenie. Do tego celu wykorzystywano głównie szybkie jednostki nawodne. Ostatnie użycie niszczycieli w formie szybkich transportowców miało miejsce pod koniec $1943 \mathrm{r}$.

2 Por. M. Kubicki, Japonska Połaczona Flota w I bitwie pod Guadalcanal 12-13 listopada 1942 roku, „Gdańskie Studia Azji Wschodniej” 2018, z. 14, s. 141-150.

3 Z. Flisowski, Burza nad Pacyfikiem, t. 1, Poznań 1986, s. 456; idem, Na wodach Guadalcanalu, Poznań 1990, s. 206. 
z ciężkich krażzowników „Chôkai” (F), „Kinugasa”, „Maya”, „Suzyua”, lekkich krążowników „Isuzu”, „Tenryū” w osłonie 6 niszczycieli'. Dowództwo nad zespołem sprawował, osławiony w bitwie pod Savo, wiceadmirał Gunichi Mikawa. Jego zadaniem było ostrzelanie lotniska Henderson Field, głównego celu Japończyków na Guadalcanal. Drugą grupę jednostek tworzył uszczuplony wskutek ataków amerykańskiego lotnictwa zespół desantowy pod dowództwem kontradmirała Raizō Tanakiego ${ }^{5}$. Było to jedno $\mathrm{z}$ największych przedsięwzięć podjętych $\mathrm{w}$ ramach akcji „Tokyo Express”. Równolegle do tych działań w okolicy wyspy, w odległości około $250 \mathrm{Mm}$ od pozycji tonącego wówczas krążownika liniowego „Hiei”, znajdował się zespół pod dowództwem wiceadmirała Nobutake Kondo 7 . Razem tworzyły one zespół ostrzału, w skład którego wchodziły: krążownik liniowy „Kirishima”, ciężkie krążowniki „Atago” (F), „Takao”, lekkie krążowniki „Sendai”, „Nagara” oraz niszczyciele: „Asagumo”, „Ayanami”, „Hatsuyuki”, „Inazuma”, „Kagero”, „Oyashio”, „Samidare”, „Shikinami”, „Shirayuki”, „Teruzuki” i „Uranami”.

Równolegle do japońskiego podziału sił na akwenach okalających Wyspy Salomona analogiczne ruchy zostały wykonane przez dowódców US Navy. Spośród sił tworzących TF 16 wydzielono siły TF 64 pod dowództwem kontradmirała Willisa Augustusa Lee. Trzon zespołu stanowiły okręty liniowe USS „South Dakota” oraz USS „Washington” w osłonie niszczycieli: USS „Benham”, USS „Gwin”, USS „Preston” i USS „Walke". Kontradmirał Lee miał za zadanie przede wszystkim przemieszczenie w kierunku wybrzeży Guadalcanal kolejnego „Tokyo Express” oraz przeciwdziałanie siłom dowodzonym przez wiceadmirała Nobutake Kondo.

Standardowym elementem operacji organizowanych przez Połączoną Flotę było rozdrobnienie sił na niewielkie zespoły, przy czym dowodzenie nimi i synchronizacja ich działań wymagały oprócz dobrej łączności radiowej doskonałego wyćwiczenia.

4 W skład eskadry niszczycieli osłony weszły: „Arashio”, „Asashio”, „Kazagumo”, „Makigumo”, „Michishio”, „Yugumo”; J. Lipiński, Druga wojna śniatowa na moræu, Warszawa 2010, s. 501; S. Piereslegin, E. Piereslegin, Premiera na Pacyfiku, t. 2, Gdańsk 2006, s. 162.

5 Konwój w momencie rozpoczęcia operacji składał się z 11 transportowców. Wraz z trwaniem rejsu amerykańskie samoloty lądowego bazowania zatopiły: „Sado Maru”, „Shinanogawa Maru”, „Nako Maru”. Jeszcze w czasie trwania I bitwy morskiej pod Guadalcanal statki wykonały pozorowany manewr odwrotu, co skutecznie zmyliło Amerykanów. Po zapadnięciu zmierzchu Tanaka nakazał powrót na kurs i dalsze zbliżanie się do Guadalcanal. Z. Flisowski, Na wodach..., s. 210.

6 „Hiei” został fatalnie uszkodzony podczas I bitwy pod Gudalcanal. Później dobity przez samoloty lądowego bazowania z Henderson Field.

Zdaniem Samuela E. Morisona wiceadmirał Kondo nalegał na jak najszybsze wysadzenie desantu w celu wzmocnienia sił japońskich na Guadalcanal. Jednym z elementów operacji miało być ostrzelanie lotniska przez zespół wiceadmirała Gunichi Mikawy. Nobutake Kondo zastapił na stanowisku dowodzącego tą operacją wiceadmirała Takeo Kuritę. S.E. Morison, Guadalcanal, tłum. R. Jędrusik, Gdańsk 2004, s. 256.

$8 \quad$ Ibidem, s. 233-234; Z. Flisowski, Burza..., s. 457, 458. 
Tak miało być i tym razem. Doświadczony wiceadmirał Mikawa skierował swoją eskadrę w kierunku Guadalcanal. W ten sposób realizował powierzone mu zadanie eliminacji lotniska Henderson Field. Ten element taktyczny, oprócz zniszczenia ważnego obiektu strategicznego, miał niwelować amerykańskie panowanie w powietrzu, największe zagrożenie dla sił desantowych kontradmirała Tanakiego.

Wiceadmirał Mikawa, znając doskonałość amerykańskiego rozpoznania lotniczego, postanowił zbliżyć się do Guadalcanal od zupełnie innej strony. Jego wybór padł na kierunek północny, od strony wysp Choiseul oraz Santa Isabel' ${ }^{9}$ Zespól bombardujacy został podzielony na dwie mniejsze eskadry. Pierwsza z nich, dowodzona przez kontradmirała Shōji Nishimurę i składająca się z ciężkich krążowników „Suzuya” (F) i „Maya”, otrzymała zadanie bombardowania lotniska ${ }^{10}$. Pozostałe jednostki pod dowództwem wiceadmirała Mikawy miały patrolować akwen i osłaniać zespół bombardujący przed interakcją z okrętami US Navy. Ostrzał zakończył się 14 listopada 1942 r. około godz. 2.05 ${ }^{11}$. Po wykonaniu zadania Mikawa zarządził odwrót. Rano 14 listopada samoloty zwiadowcze z Guadalcanal i USS „Enterprise”, wchodzącego w skład zespołu TF 16 wykryły siły japońskie w odległości około $140 \mathrm{Mm}$ od cieśniny Slot. Rozpoczął się pościg, w efekcie którego ciężki krążownik „Kinugasa” zatopiono, zaś uszkodzono ciężkie krążowniki „Chôkai”, „Maya”, lekki krążownik „Isuzu” oraz niszczyciel „Michishio”"12.

W trakcie uderzenia powietrznego na siły wiceadmirała Mikawy około godziny 7.00 amerykański zwiad powietrzny wykrył zespół desantowy pod dowództwem kontradmirała Tanakiego ${ }^{13}$. Po dokonaniu głębokiego rozpoznania okazało się, że są to te same statki, które w dniu poprzednim zdążały w kierunku Guadalcanal. Rozpoczęła się seria nalotów wykonana siłami samolotów lądowego bazowania oraz grupy lotniczej pochodzącej z USS „Enterprise”14. W efekcie amerykań-

9 Dzięki temu manewrowi siły Mikawy uniknęły kontaktu z amerykańskimi samolotami rozpoznawczymi. Wysłane okręty liniowe USS „South Dakota” oraz USS „Washington” nie zdążyły dotrzeć na pole bitwy, dlatego nie mogły przechwycić sił przeciwnika.

10 Ostrzał rozpoczął się o godzinie 1.28. Przeprowadzony został przez okręty pod dowództwem kontradmirała Shōji Nishimury i był bardzo nieskuteczny. W efekcie już następnego ranka lotnisko Henderson Field było gotowe do obsługi samolotów. Efektem były późniejsze uderzenia lotnicze na zespół Mikawy. A. Schom, Wojna na Pacyfiku. Od Pearl Harbour do Guadalcanal. Wodzowie, strategia, dyplomacja, tłum. S. Kędzierski, Warszawa 2007, s. 426-427.

11 W efekcie ostrzału lotniska Henderson Field zniszczono zaledwie kilka amerykańskich samolotów.

12 Jednym z zadań przydzielonych wiceadmirałowi Mikawie było pełnienie funkcji przynęty dla amerykańskiego lotnictwa. Taktyka ta okazała się bardzo kosztowna, ponieważ większość okrętów wchodząca w skład zespołu została uszkodzona. Zdaniem Jerzego Lipińskiego w ataku na okręty japońskie brały udział również amerykańskie ścigacze torpedowe. Ciężki krążownik „Kinugasa” zatonął o godzinie 11.22. J. Lipiński, Druga wojna..., s. 501.

13 W skład konwoju wchodziło również 11 niszczycieli osłony.

14 Z. Flisowski, Burza..., s. 458. 
skich uderzeń lotniczych zatopiono: „Arizona Maru”, „Brisbane Maru”, „Canberra Maru”, „Nagara Maru” ${ }^{15}$. Jednocześnie pierwsza próba przerzucenia przez Japończyków większej ilości wojska w ramach rozbudowanego desantu wraz ze sprzętem i zaopatrzeniem okazała się zupełnie nieefektywna ${ }^{16}$. Po tych wydarzeniach kontradmirał Tanaka około 17.00 zlecił dokonanie pozornego zwrotu na północ i utrzymywanie takiego kierunku marszu do 20.00, kiedy ponownie jego jednostki miały skierować się na południe. Pomimo poniesionych strat dowódca zdecydował się kontynuować rejs w kierunku Guadalcanal.

14 listopada 1942 r. około 10.00 wiceadmirał Kondo podjął decyzję o wyruszeniu w kierunku Guadalcanal. Do tego momentu Amerykanie nie mieli dokładnych informacji na temat położenia sił Połączonej Floty. Zdawali sobie jednak sprawę, że w rejonie Wysp Salomona znajduje się silny zespół japoński. W trakcie przemarszu w kierunku wyspy Kondo był nieskutecznie atakowany przez amerykański okręt podwodny USS „Trout" ${ }^{\prime 17}$. Po zapadnięciu zmroku w regionie Guadalcanal znajdowały się okręty pod dowództwem kontradmirała Lee, które borykały się z brakiem łączności ${ }^{18}$. W tym samym czasie w kierunku wyspy podążała eskadra pod dowództwem wiceadmirała Kondo, której wyznaczono zadania zniszczenia sił przeciwnika oraz zbombardowania Henderson Field. W tym celu japoński dowódca podzielił swoje siły na trzy grupy. Pierwsza, zwana grupa dalekiej osłony, została sformowana wokół lekkiego krążownika „Sendai” pod dowództwem kontradmirała Shintaro Hashimoto, drugą stanowily lekki krążownik „Nagara” wraz z sześcioma niszczycielami, a trzecią okręty grupy ostrzału - krążownik liniowy „Kirishima” oraz ciężkie krążowniki „Atago” i „Takao”. W takim składzie Japończycy zdążali w kierunku Guadalcanal.

Około godziny 22.10 załoga lekkiego krążownika „Sendai” nawiązała kontakt z „dwoma niezidentyfikowanymi ciężkimi krążownikami i czterema niszczycielami”' ${ }^{\prime \prime}$. Były to okręty pod dowództwem kontradmirała Lee. Pomimo wyposażenia amerykańskich okrętów w radary tym razem inicjatywa strategiczna i element

15 Zdaniem Tameichiego Hary już na etapie nalotów zatopiono 7 transportowców. Jerzy Lipiński określa liczbę zatopionych transportowców na 6 . Informacja ta nie znajduje potwierdzenia w innych materiałach. T. Hara, Dowódca niszrçyciela, tłum. A. Pogorzelski, Gdańsk 2003, s. 220; J. Lipiński, Druga wojna..., s. 501.

${ }_{16}$ Zdecydowały o tym takie czynniki, jak bardzo słaba osłona powietrzna, brak rozpoznania oraz brak osłony, która dysponowałaby samolotami (lotniskowce).

17 Po wykonaniu nieudanego ataku na japońskie okręty dowódca USS „Trout” nadał meldunek o wykryciu sił wroga. Potwierdził on amerykańskie przekonanie o przebywaniu w regionie Guadalcanal silnego zespołu. Zdaniem Alana Schoma zespól wiceadmirała Kondo został wykryty około godziny 9.00 przez pilotów samolotów z USS „Enterprise”, co pozwoliło na lepsze przygotowanie strony amerykańskiej. A. Schom, Wojna na Pcyfiku..., s. 428.

18 Kontradmirał Lee miał problem z nawiązaniem łączności z kwatera główną na Guadalcanal.

19 Jerzy Lipiński wskazuje, że jako pierwszy kontakt z zespołem japońskim nawiązał USS „Washington”. J. Lipiński, Druga wojna..., s. 501. 
zaskoczenia leżały po stronie japońskiej. Na polecenie wiceadmirała Kondo niszczyciele zgrupowane wokół „Sendai” miały dokonać rozpoznania i rozpocząć pościg za nieprzyjacielem. Amerykanie, nie wiedząc o nawiązaniu kontaktu z wrogiem, nadal prowadzili patrol. Ich okręt flagowy USS „Washington” wykrył Japończyków za pomoca radaru dopiero o 22.52. W efekcie o 23.12 kontradmirał Lee wydał swoim jednostkom rozkaz otwarcia ognia. Ich celem był lekki krążownik „Sendai”, który wskutek ostrzału został zmuszony do postawienia zasłony dymnej i wycofania się ${ }^{20}$. Następnie doszło do wykrycia przez USS „Walke” japońskich niszczycieli „Ayanami” i „Uranami”, które znajdowały się na południe od wyspy Savo. Amerykanie nawiązali kontakt z grupa straży przedniej. Między Połączoną Flotą i US Navy rozpoczął się pojedynek artyleryjski.

Równolegle do tych wydarzeń do akcji weszły amerykańskie okręty liniowe USS „South Dakota” i USS „Washington”. Pierwszy z nich o 23.33 wskutek trafienia japońskim pociskiem stracił zasilanie. Na polu bitwy powstało całkowite zamieszanie. O 23.38 amerykańskie niszczyciele USS „Walke” i USS „Benham” po otrzymaniu kilkunastu celnych trafień ze strony Japończyków zostały storpedowane ${ }^{21}$. Uszkodzeń nie uniknęły również USS „Preston” i USS „Gwin”, wielokrotnie trafione przez okręty pod dowództwem kontradmirała Kimury. Po tym dynamicznym starciu japońskie okręty zaczęły wycofywać się z rejonu, od rufy atakując siły główne kontradmirała Lee. Załogi USS „South Dakota” i USS „Washington” nie były w stanie zorientować się w sytuacji i zlokalizować sił pod dowództwem Kimury. Świadczyło to o braku zdecydowania wiceadmirała Kondo, który nie był w stanie wykonać skoordynowanego uderzenia na słabszy zespół amerykański. O godzinie 23.35 cztery amerykańskie niszczyciele, które zostały zaskoczone przez siły japońskie, były wyłączone z akcji122. Po stronie Połączonej Floty ciężko uszkodzony został niszczyciel „Ayanami”23.

Kontradmirał Lee o 23.48 wydał rozkaz rozpoczęcia pojedynku artyleryjskiego z siłami Połączonej Floty. Na USS „South Dakota” przywrócono zasilanie i okręt przygotowywał się do walnej bitwy. Wskutek zmian kursowych oddalił się jednak od USS „Washington”, tracąc drugi okręt liniowy z pola widzenia, a manewr ten jednocześnie przybliżł go do zespołu kontradmirała Kimury. Odpowiedź japońskiego dowódcy była błyskawiczna. Po stwierdzeniu kontaktu z wrogiem nakazał on wystrzelenie pełnej salwy 34 torped w kierunku wykrytego okrętu US Navy ${ }^{24}$.

\footnotetext{
20 S.E. Morison, Guadalcanal..., s. 269, 271; A. Schom, Wojna na Pacyfiku..., s. 430.

21 Kontradmirał Kimura stał na czele zespołu osłony. Jego okrętem flagowym był lekki krążownik „Nagara”.

22 Po zakończeniu starcia artyleryjskiego zatoną USS „Walke” oraz USS „Preston”. USS „Benham” zatonął następnego dnia.

23 Przy burcie niszczyciela „Ayanami” oczekiwał niszczyciel „Uranami”, który w razie zatonięcia jednostki miał podjąć jej załogę.

24 S. Piereslegin, E. Piereslegin, Premiera ..., s. 172.
} 
Żadna z nich nie trafila w cel. W tym samym czasie jednostki grupy ostrzału pod dowództwem wiceadmirała Kondo nie wzięły udziału w starciu. Dopiero o 23.55 dowódca nakazał zwrot i włączenie się do walki, co miało jego zdaniem dopomóc znajdującemu się w trudnej sytuacji Kimurze. Ten drugi w tym momencie oddalał się od sił amerykańskich, wystawiając na atak siły podległe wiceadmirałowi Kondo ${ }^{25}$.

Podchodzące do USS „South Dakoty” okręty Połączonej Floty nadal pozostawały niewykryte. Wiceadmirał Kondo po zbliżeniu się do amerykańskiego okrętu liniowego na odległość 4500 m nakazał oświetlenie celu i otwarcie ognia. Po raz drugi w tej bitwie odpalono salwę torped, która pomknęła w kierunku Amerykanów, ale okazała się zupełnie nieskuteczna. Japoński dowódca nakazał skupienie ognia wszystkich okrętów na USS „South Dakota”, nie zdając sobie sprawy, że w regionie operuje drugi ciężki okręt wroga. USS „Washington” oczekiwał na rozwój sytuacji, ponieważ nie mógł zlokalizować bliźniaczego krążownika liniowego na polu bitwy ${ }^{26}$. Sytuacja stała się o wiele bardziej klarowna, gdy jednostki Połączonej Floty oświetliły USS „South Dakotę”. O północy 15 listopada 1942 r. kontradmirał Willis Lee nakazał otwarcie ognia i skupienie go na największym celu, jakim był krążownik liniowy „Kirishima”. W wyniku amerykańskiego ostrzału okręt otrzymał wiele trafień, które najpierw unieruchomiły go, a następnie wyłączyły z dalszej akcji27.

Po fatalnym uszkodzeniu „Kirishimy” wiceadmirał Kondo oraz podlegli mu dowódcy zauważyli, że na polu bitwy pojawił się drugi okręt liniowy. Japończycy podzielili ogień między dwie amerykańskie jednostki. W efekcie starcia USS „South Dakota" został wielokrotnie trafiony pociskami różnych kalibrów, co spowodowało średnie uszkodzenia oraz zerwało łączność zewnętrzną i wewnętrzną ${ }^{28}$. Na USS „Washington”, który pojawił się późno na polu bitwy, uszkodzenia były nieznaczne. Starcie zakończyło się około godziny 00.20.

Wiceadmirał Kondo, który dopiero po wyłączeniu „Kirishimy” z akcji zorientował się w swoim położeniu, zlecił dalszą obserwację sytuacji. Stan ten trwał do godziny 00.25 , kiedy wskutek niepomyślnych wieści japoński dowódca nakazał odwrót i jednoczesne przerwanie misji ostrzału lotniska Henderson Field. Analogiczny

25 W tym czasie zespół bombardujący pod dowództwem wiceadmirała Nobutake Kondo składał się z: krażzownika liniowego „Kirishima”, ciężkich krążowników „Atago” i „Takao” oraz niszczycieli „Asagumo” i „,Teruzuki”. Kontradmirał Kimura zameldował wiceadmirałowi Kondo o wykryciu wrogiego okrętu liniowego.

${ }_{26}$ Zdaniem Zbigniewa Flisowskiego w momencie oczekiwania na rozstrzygnięcie sytuacji USS „South Dakota” znajdował się w martwym polu radaru USS „Washington”. Kontradmirał Lee ze względu na duże zamieszanie panujące na polu bitwy wstrzymał się z decyzją o otwarciu ognia, co należy uznać za słuszne posunięcie. Z. Flisowski, Burža..., s. 467.

27 W sumie krążownik liniowy „Kirishima” został trafiony 9 pociskami kal. $406 \mathrm{~mm}$ oraz 40 pociskami $127 \mathrm{~mm}$, co dla sędziwego okrętu, jakim była „Kirishima”, okazało się śmiertelne.

${ }_{28} \mathrm{Na}$ USS „South Dakota” wskutek trafienia 42 pociskami uszkodzono również jedną z wież artylerii głównej oraz wybuchło wiele drobnych pożarów. 
rozkaz wydał kontradmirał Lee o godzinie 00.33, jednak amerykański dowódca nie posiadał w tamtej chwili żadnych informacji na temat losu USS „South Dakota”29. W trakcie uchodzenia USS „Washington” z pola bitwy został on bezskutecznie zaatakowany salwa torpedowa przez „Kagero” i „Oyashio” wydzielone z zespołu kontradmirała Tanakiego.

Ostatnimi akordami bitwy były agonia „Kirishimy” i los konwoju zaopatrzeniowego kontradmirała Tanakiego. Wiceadmirał Kondo pozostawił przy burcie uszkodzonego okrętu niszczyciele, których zadaniem było osłanianie krążownika ${ }^{30}$. W tym momencie „Kirishima” miała uszkodzony układ napędowy i sterowania, co utrudniało prowadzenie akcji ratunkowej. Ostatecznie jednostka została samozatopiona przez załogę 15 listopada 1942 r. około godziny 3.2031. Wśród japońskich okrętów zatonął również niszczyciel „Ayanami”, który uległ niemal całkowitemu zniszczeniu wskutek amerykańskiego ostrzału. Finałem drugiej bitwy pod Guadalcanal było wysztrandowanie na brzegu wyspy lub przybrzeżnych płyciznach czterech ostatnich transportowców z wojskiem: „Hirokawa Maru”, „Kinugawa Maru”, „Yamamura Maru” oraz „Yamatsuki Maru”32. Po wyładowaniu około 2 tys. żołnierzy, niewielkiej części zaopatrzenia i uzbrojenia zostały one zniszczone przez amerykańskie lotnictwo i niszczyciel USS „Meade”33.

Przeprowadzona w nocy z 14 na 15 listopada 1942 r. bitwa była przykładem klasycznego starcia okrętów liniowych. Kontradmirał Willis Lee wykazał się w niej o wiele większym kunsztem wojennym. Wiceadmirał Nobutake Kondo podszedł do starcia $z$ charakterystyczną dla siebie ostrożnością. Po raz kolejny okazało się, że decydująca na polu bitwy przewaga technologiczna leży po stronie amerykańskiej. Uwidoczniła się ona w wyposażeniu poszczególnych okrętów w radary, w tej bitwie słabo wykorzystane, oraz treningu walki nocnej. O ile pierwszy z elementów wynikał z przewagi technologicznej Stanów Zjednoczonych nad Cesarstwem Japonii, o tyle drugi był efektem poprzednich bitew, w których uczestniczyła US Navy. Druga bitwa morska pod Guadalcanal stanowiła jeden z efektów przesilenia w kampanii na Wyspach Salomona. Strona japońska nie była w stanie przeciwdziałać panowaniu w powietrzu, jakie US Army zyskała dzięki niepodzielnemu posiadaniu lotniska Henderson Field. Uwidoczniły się też przestarzałe schematy dowodzenia i planowania operacji w Połączonej Flocie, gdzie zespoły współdziałające ze soba zostały rozproszone na zbyt dużych obszarach. Choć obie strony popełniły wiele

29 Z. Flisowski, Burza..., s. 468.

30 S.E. Morison, Guadalcanal..., s. 277, 278.

31 T. Hara, Dowódca..., s. 220; S. Piereslegin, E. Piereslegin, Premiera ..., s. 172.

32 Japońskim transportowcom towarzyszyły również niszczyciele, na których pokładach znajdowali się żołnierze przeładowani z zatopionych wcześniej jednostek. Zdaniem Samuela E. Morisona nie zostali oni wyładowani na brzegu Guadalcanal, lecz ewakuowani na Wyspę Shortland, gdzie jednostki dotarły 15 listopada $1942 \mathrm{r}$.

33 S.E. Morison, Guadalcanal..., s. 279-281. 
błędów, to Japończycy zdecydowanie więcej. Na pierwszy plan wysuwa się w tej materii niewykorzystanie wypracowanego elementu zaskoczenia przez siły wiceadmirała Kondo. Opisywana II bitwa morska pod Guadalcanal była japońską klęską zarówno taktyczna, jak i strategiczną.

\section{SUMMARY}

\section{THE JAPANESE COMBINED FLEET IN THE SECOND BATTLE OF GUADALCANAL, NOVEMBER 14-15, 1942}

The purpose of the article is to present the clash of the night of November 14-15, 1942, which has gone down in the history of maritime warfare as the Second Battle of Guadalcanal. It was the result of the efforts of Japan and the United States to solve the complex strategic situation on the Solomon Islands archipelago. It was also the effect of a highpoint in the campaign, which finally ended in the defeat of the Japanese Empire. During the battle, the ills of the Japanese command system, officers' indecision, and technological backwardness came to light. One of the elements that contributed to the American victory was air control provided by planes taking off from Henderson Field airfield. Thanks to efficient command, US Navy ships with the help of aviation inflicted considerable losses within the Japanese ranks. As a result, the Second Battle of Guadalcanal ended in the total defeat of the Empire, whose situation in the Solomon Islands deteriorated subsequently. 